Journal of Urban and Regional Analysis, vol. XIII, 1, 2021, p. 19 - 34

https://doi.org/10.37043/JURA.2021.13.1.2

\title{
THE ROLE OF COOPERATION IN THE INNOVATION ACTIVITY OF ENTERPRISES: THE CASE OF POLISH REGIONS
}

\author{
Judyta LUBACHA \\ Jagiellonian University, Cracow, Poland, \\ Cracow University of Economics, Cracow, Poland
}

\begin{abstract}
Innovations are seen as an important factor of regional growth, but what influences the innovation activity of enterprises? In the regional innovation system, the set of actors interacting with each other is surrounded with a specific socio-economic environment. In the present research, the following economic and social features in a region - human capital, social capital, the level of economic development, and the existence of FDI - are analysed as possible factors of the innovation activity undertaken by enterprises. Two types of innovation activity are analysed: in-house R\&D and the acquisition of machinery, software and equipment. The analysis was conducted for the years: 2004-2006, 2006-2008, 2008-2010, 2010-2012, 2012-2014, and the 16 Polish NUTS-2 regions. Based on the results of econometric panel models, innovation cooperation was found to be significant and positively related with both types of innovation activity. Moreover, public financial support and the level of foreign capital involvement were found positively related with the in-house R\&D activity.
\end{abstract}

Key Words: regional innovation system, innovation cooperation, panel data models.

\section{Introduction}

According to the economic theory (Abramovitz 1956, Solow 1956, Solow 1957, Romer 1990), innovativeness is one of the main factors of economic growth. At regional level, researchers found the same relationship - a level of innovativeness can explain the differences in the development of individual regions (Niedzielski and Jaźwiński 2002, Crescenzi 2005, Fagerberg and Godinho 2005, Cooke et al. 2011). The development of a knowledge-based economy is also one of the main goals of the European Union. "Innovation Union" was set out as one of the priorities of the Europe 2020 Strategy (European Commission 2010a). The need for smart growth at a regional level was also noticed, and the Smart Specialisation approach was introduced as part of the "Innovation Union" programme to promote innovations in EU regions (European Commission 2010b).

The two main types of innovations are the products and the process innovations. They can be introduced in various ways: e.g. internal $R \& D$, external $R \& D$, acquisition of machinery, software and equipment, acquisition of patents and licencing (OECD and Eurostat 2018). Internal R\&D activity is seen as an important factor in the catching-up process (Segerstrom 1991, Davidson and Segerstrom 1998, Griffith et al. 2004). Although, there is some evidence at national level that in-house activity occurs more often in more developed countries, and the acquisition of machinery, equipment, and knowledge is more often considered as a way to innovate in catching-up countries (Nölke and Vliegenthart 2009, Veugelers and Mrak 2009, Radosevic and Kaderabkova 2011, Geodecki 2014, Grodzicki and Geodecki 2016, Lopez-Rodriguez and Martinez 2017).

However, most of the research on the determinants of regional innovativeness (Pangsy-Kania 2007, Crescenzi and Rodríguez-Pose 2011, Czupich 2012, Paas and Triin 2012, Naz et al. 2015, Dzemydaitè et al. 2016, Krakowiak-Bal and Ziemiańczyk 2017, Dziallas and Blind 2019) only measures innovation using indicators related to the R\&D activity such as R\&D 
expenditure, R\&D personnel or the number of patent applications. Martin (2013) underlined this omission as a challenge faced by studies on innovations. Similarly, Pino and Ortega (2018) stressed out the lack of appropriate measures of RIS in previous research. The present research tries to fill this gap and to analyse both the main ways of introducing innovations internal R\&D, and the acquisition of machinery, software and equipment. It is assumed that both these types need different preconditions and the existence of different socio-economic features within regions. The main aim of the research is to identify the regional factors of both types of innovation activity to support the understanding of how the regional environment influences the various ways of implementing innovation within regions.

The paper is structured as follows. Section 2 introduces a theoretical framework. The data employed and methodology are explained in Section 3. Section 4 presents the results which are discussed in Section 5.

\section{Theoretical framework}

The theoretical base to the conducted research is the concept of regional innovation systems (RIS). The regional innovation system concept is an analytical model of innovation activity in regions (Braczyk et al. 1998). Despite much research on RISs (Wiig and Wood 1995, Asheim and Isaksen 1997, Cooke et al. 1997, Autio 1998, Howells 1999, Doloreux 2002, Evangelista et al. 2002, Doloreux and Parto 2005, lammarino 2005, Świadek 2011, Todtling and Trippl 2011, Weresa 2013), there is a lack of a common definition. In most cases, an RIS is understood as a set of interacting private and public units, formal institutions and other organisations focused on the generation, use and diffusion of knowledge (Doloreux and Parto 2004), or in a broader sense focused on the production, import, modification, and diffusion of new technologies (Evangelista et al. 2002). At the base of this concept lies an assumption that innovation activity is a non-linear and strongly interactive process, and that innovative firms do not operate in isolation. The concept underlines the importance of communication and cooperation between different actors such as enterprises, universities, educational units, financial units, firms, associations, and governmental agencies. Innovative processes are geographically localised, and territorial features, among others, are reflected in the technological systems, production processes, manufacturing organisation, social and political surroundings. Also, some of the factors of innovation, such as tacit knowledge or institutions, are immobile to some extent (Cooke and Morgan 1998, Nauwelaers 2011, Todtling and Trippl 2011). Moreover, Doloreux and Gomez (2017) underlined the evolutionary and dynamic nature of RIS.

Previous research on RISs, in most cases, is based on case studies (Wiig and Wood 1995, Asheim and Isaksen 1997, Acs et al. 1998, Smith et al. 1998, Asheim and Isaksen 2002, Gerstlberger 2004, lammarino 2005, Innovating Regions in Europe 2008, Florio et al. 2014, Ligenzowska 2016). Qualitative research was based, among others, on the IAIF-RIS database (Buesa et al. 2007), the Eurostat database (Hájková and Hájek 2010), on surveys (Świadek 2011), and on R\&D and patent statistics (Weresa 2012). The Community Innovation Survey (CIS) at regional level was successfully used by Evangelista et al. (2002), among others, but that research rarely referred to the Polish regions. In the present analysis, the RISs of Polish regions are pictured in a quantitative way by using detailed data from the Community Innovation Survey (CIS).

In the present research, the following dimensions of RISs are measured: innovation activity of enterprises, involvement of the public sector in R\&D, human capital, social capital (namely social trust and the social tendency to network), and the innovation cooperation of enterprises with any public or private partner. Human capital is defined after Becker et al. (1990: 15) as 'embodied knowledge and skills', while social capital is understood as social trust, norms of reciprocity, and networks of civic engagement (Putnam et al. 1993). 
Regions differ significantly according to the quantity and quality of the factors of innovations, such as: the quality of institutions, the relations between innovative entities, intangible assets (such as human capital, social capital), and cultural aspects (Council on Competitiveness 2005, Kosała and Wach 2011, Nowakowska 2011, Markowska 2012, Camagni and Capello 2013 , Crescenzi and Rodriguez-Pose 2013, Park 2015). It is assumed that the differences in the following economic and social features in a region - human capital, social capital, level of economic development, and the existence of FDI - can influence the type of innovation activity undertaken by the enterprises. Four hypotheses are tested in the research. H1: A higher level of human capital in a region is positively related to the engagement of innovative enterprises in in-house R\&D. Human capital was found to be an important factor in innovations in a region in previous research (Broekel and Brenner 2011, Bellmann et al. 2013, Naz et al. 2015). H2: A higher level of innovative cooperation is positively related to the engagement of innovative enterprises in in-house R\&D. Networks of cooperation are seen as an important element of the regional innovation environment (Tura and Harmaakorpi 2010), and a crucial part of the innovation system, where various actors interact with each other (Cooke et al. 1997, Autio 1998, Howells 1999, Doloreux 2002, Doloreux and Parto 2005). H3: A higher level of FDI in a region is positively related to the engagement of innovative enterprises in the acquisition of machinery and equipment. Fu (2008) suggested that the role of FDI in the development of innovations can be of a twofold nature, and it depends on the type of investment. On the one hand, for low-cost production and export-oriented investments, FDI would support the acquisition of already developed technologies and licencing. On the other hand, for R\&D investments, FDI would support internal R\&D in the region of the investment, but then a high level of regional human capital is a precondition. In the case of Poland and the manufacturing sector, the former was found to be predominant (Grodzicki and Geodecki 2016). H4: A higher level of public financial support in a region is positively related to the engagement of innovative enterprises in in-house R\&D. Mazzucato (2013) underlined the role of public financing in innovation development.

\section{Methodology}

The analysis was conducted for the years: 2004-2006, 2006-2008, 2008-2010, 2010-2012, 2012-2014 (the years of the analysis are based on the availability of social diagnosis and the Community Innovation Survey data), and for the 16 Polish NUTS-2 regions: Łódzkie (PL11), Mazowieckie (PL12), Małopolskie (PL21), Śląskie (PL22), Lubelskie (PL31), Podkarpackie (PL32), Świętokrzyskie (PL33), Podlaskie (PL34), Wielkopolskie (PL41), Zachodniopomorskie (PL42), Lubuskie (PL43), Dolnośląskie (PL51), Opolskie (PL52), Kujawsko-Pomorskie (PL61), Warmińsko-Mazurskie (PL62), Pomorskie (PL63). To identify clusters of regions with a similar level of indicators for the features of a regional innovation system (Table 1), hierarchical clustering methods (namely, the Ward's method) were applied ${ }^{2)}$. Calculations were done in the $\mathrm{R}$ environment with the stats package (R Core Team 2018).

To examine the relationship between the various elements of the socio-economic environment (human capital, social capital, public sector financial support, FDI) and the engagement of innovative enterprises in an innovation activity, the estimation of the econometric panel models for the selected variables was performed. Calculations were done in the $R$ environment ( $R$ Core Team 2018) using the plm package (Croissant and Millo 2008). The panel was built for 16 Polish NUTS-2 regions over five sets of years (2004-2006, 2006-2008, 2008-2010, 2010-2012, 2012-2014). The model (pooled) is based on the classical OLS regression estimated using an à

1) Data from CIS were delivered by the Polish National Statistical Office (GUS) in the form of aggregated data at NUTS-2 level. The acquisition of data was financed by the National Science Centre, Poland, grant no. 2016/21/N/HS4/02098.

2) For example, Yuan et al. (2013) tested a more advanced grey fixed weight clustering method in their research. 
Indicators used as quantitative measures of RIS components

\begin{tabular}{|c|c|c|c|}
\hline $\begin{array}{l}\text { RSI compo- } \\
\text { nent }\end{array}$ & Indicator & Basic data name/label & $\begin{array}{c}\text { Source } \\
\text { [indicator code] }\end{array}$ \\
\hline \multirow[t]{2}{*}{ Human capital } & K1 & $\begin{array}{l}\text { \% of graduates (ISCED } 1997 \text { level 5) in physics, } \\
\text { chemistry, biology, mathematics and computing, } \\
\text { informatics, environmental protection, engineer- } \\
\text { ing, manufacturing and processing, architecture } \\
\text { and construction, as a percentage of graduates } \\
\text { of public and private higher education units in all } \\
\text { fields }\end{array}$ & $\begin{array}{l}\text { Central Statistical } \\
\text { Office of Poland } \\
\text { (GUS) }\end{array}$ \\
\hline & $\mathrm{K} 2$ & $\begin{array}{l}\text { Scientists and engineers as percentage of the } \\
\text { active population }\end{array}$ & $\begin{array}{l}\text { Eurostat } \\
\text { [hrst_st_rcat] }\end{array}$ \\
\hline Social capital & $\mathrm{N} 1$ & $\begin{array}{l}\text { Percentage of respondents who are members of } \\
\text { one or more associations }\end{array}$ & $\begin{array}{l}\text { Social } \\
\text { Diagnosis (2016) }\end{array}$ \\
\hline \multirow[t]{2}{*}{ Cooperation } & $\mathrm{C} 1$ & $\begin{array}{l}\text { Percentage of innovative enterprises } \\
\text { (manufacturing sector) engaged in any type of } \\
\text { cooperation }\end{array}$ & GUS \\
\hline & $\mathrm{C} 2$ & $\begin{array}{l}\text { Percentage of PCT co-patent applications made } \\
\text { within the region }\end{array}$ & OECD \\
\hline \multirow{3}{*}{$\begin{array}{l}\text { Innovation } \\
\text { activity of } \\
\text { enterprises }\end{array}$} & IA1 & $\begin{array}{l}\text { Average rate of innovative enterprises in the } \\
\text { total number of enterprises }\end{array}$ & GUS \\
\hline & IA2 & $\begin{array}{l}\text { Expenditure of innovative enterprises on R\&D as } \\
\text { percentage of the total innovative activity ex- } \\
\text { penditure }\end{array}$ & GUS \\
\hline & IA3 & $\begin{array}{l}\text { Expenditure of innovative enterprises on the } \\
\text { acquisition of machinery, software and equip- } \\
\text { ment as percentage of the total innovative activi- } \\
\text { ty expenditure }\end{array}$ & GUS \\
\hline \multirow[t]{3}{*}{$\begin{array}{l}\text { Research } \\
\text { activity }\end{array}$} & RD1 & $\begin{array}{l}\text { Public sector (government }+ \text { higher education) } \\
\text { R\&D expenditure as percentage of the total R\&D } \\
\text { expenditure }\end{array}$ & $\begin{array}{l}\text { Eurostat } \\
\text { [rd_e_gerdreg] }\end{array}$ \\
\hline & RD2 & $\begin{array}{l}\text { R\&D personnel and researchers in the public } \\
\text { (government }+ \text { higher education) R\&D sector as } \\
\text { percentage of the total R\&D personnel and re- } \\
\text { searchers }\end{array}$ & $\begin{array}{l}\text { Eurostat } \\
\text { [rd_p_persreg] }\end{array}$ \\
\hline & RD3 & $\begin{array}{l}\text { Patent applications to the EPO by priority year } \\
\text { per million inhabitants }\end{array}$ & $\begin{array}{l}\text { Eurostat } \\
\text { [pat_ep_rtot] }\end{array}$ \\
\hline
\end{tabular}

la Newey and West estimator (NW) (Millo 2017).

Individual effects were tested with the Breusch-Pagan test (Breusch and Pagan 1980). Random effects were tested with the Baltagi \& Li AR-RE test (Baltagi and Li 1991, Baltagi and Li 1995). In case of individual effects, the fixed effect and random effect estimators should be tested (Baltagi 2005). The data used in the models are presented in Table 2.

Public R\&D based regions are mostly in Eastern Poland such as Podlaskie, Lubelskie and Świętokrzyskie; they are also part of a group of underdeveloped regions in Poland in terms of GDP (below $20 \%$ of the EU average in 2004, and below $30 \%$ in 2013). Diversified innovation activity regions - Małopolskie, Śląskie, Dolnośląskie, Pomorskie, and Mazowieckie - are regions with a high FDI share (from 5 [Małopolskie] to 19 [Mazowieckie] enterprises with foreign capital per 10,000 inhabitants in 2013) and a high level of new enterprise creation (almost $45 \%$ of all new enterprises created every year in Poland are established in those 
The Role of Cooperation in the Innovation Activity of Enterprises: the Case of Polish Regions

Table 2

Description of the variables used in the models for the innovation activity

\begin{tabular}{|c|c|c|c|}
\hline Variable & Description & $\begin{array}{l}\text { Data } \\
\text { source }\end{array}$ & Years covered \\
\hline \multicolumn{3}{|c|}{ Dependent variable } & \\
\hline$r d_{i t}$ & $\begin{array}{l}\text { Innovative enterprises engaged in internal } \\
\text { R\&D activity (\% of total innovative enter- } \\
\text { prises) }\end{array}$ & \multirow[t]{2}{*}{$\begin{array}{l}\text { GUS } \\
(\mathrm{CIS})^{*}\end{array}$} & \multirow{2}{*}{$\begin{array}{l}2004-2006,2006- \\
2008,2008-2010, \\
2010-2012,2012- \\
2014\end{array}$} \\
\hline$m e_{\text {it }}$ & $\begin{array}{l}\text { Innovative enterprises engaged in the } \\
\text { acquisition of machinery and equipment } \\
\text { (\% of total innovative enterprises) }\end{array}$ & & \\
\hline \multicolumn{3}{|c|}{ Independent variables (explanatory variables) } & \\
\hline$K 1_{\text {it }}$ & $\begin{array}{l}\text { Scientists and engineers as percentage of } \\
\text { the active population }\end{array}$ & Eurostat & \multirow[t]{3}{*}{$\begin{array}{l}\text { 2005, 2007, 2009, } \\
2011,2013\end{array}$} \\
\hline$C 1_{\text {it }}$ & $\begin{array}{l}\text { Percentage of innovative enterprises } \\
\text { (manufacturing sector) engaged in any } \\
\text { type of cooperation }\end{array}$ & GUS & \\
\hline FCapital it $_{1}$ & $\begin{array}{l}\text { Enterprises with foreign capital, per } \\
10,000 \text { residents }\end{array}$ & GUS & \\
\hline PublicFin $_{\text {it }}$ & $\begin{array}{l}\text { Innovative enterprises supported by the } \\
\text { national government (\% of total innovative } \\
\text { enterprises) }\end{array}$ & $\begin{array}{l}\text { GUS } \\
(\mathrm{CIS})^{*}\end{array}$ & $\begin{array}{l}2004-2006,2006- \\
2008,2008-2010, \\
2010-2012,2012- \\
2014\end{array}$ \\
\hline
\end{tabular}

*Data calculated by GUS based on CIS data

Notion: All variables are expressed in natural logarithms; variable subscriptions relate to the $i^{\text {th }}$ region in $t^{\text {th }}$ period.

Source: own elaboration

regions). Podkarpackie is an example of a private R\&D based region, and what is interesting is that data shows a low level of human capital, but a very high level of innovation cooperation. It can be assumed that capital and cooperation in the Podkarpackie region are high and they can support the innovation activity.

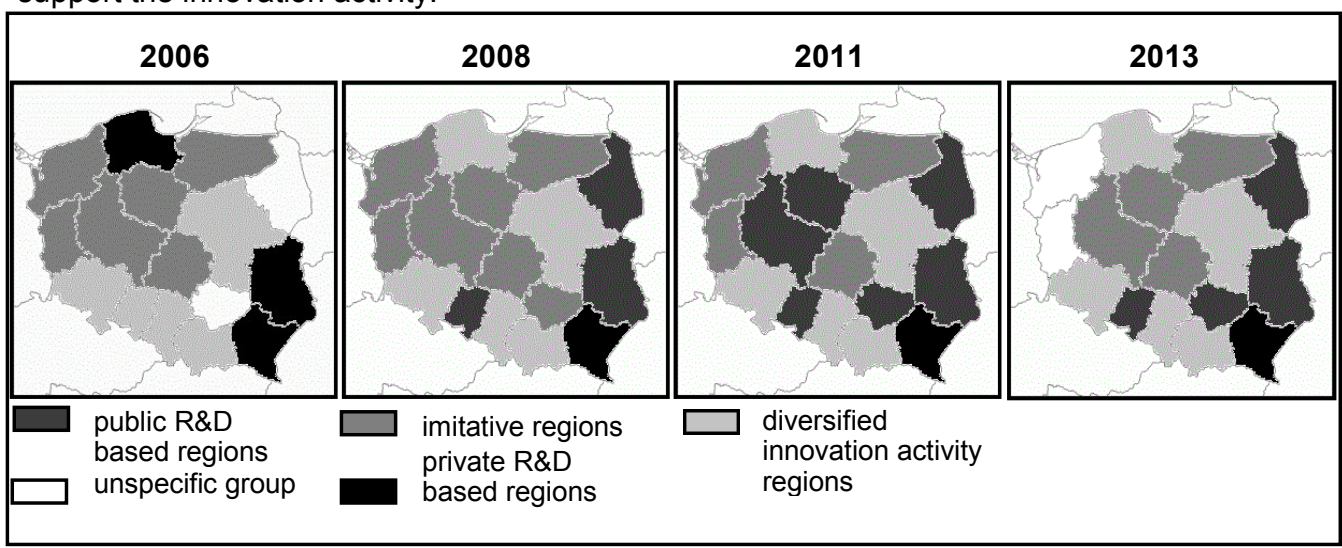

Fig. 1 - Regional innovation systems in Polish regions

Source: own elaboration 


\section{Results}

Based on the clustering results, four types of RISs in Polish regions can be identified: (1) public R\&D based regions; (2) imitative regions, (3) private R\&D based regions, (4) diversified innovation activity regions (Fig. 1 , Table 3 ).

Types of regional innovation systems

Table 3

\begin{tabular}{|c|c|c|c|}
\hline Group & Group characteristic & Group & Group characteristic \\
\hline $\begin{array}{l}\text { I- public } \\
\text { R\&D } \\
\text { based } \\
\text { regions }\end{array}$ & $\begin{array}{l}\text { - Low or very low level of } \\
\text { human capital } \\
\text { - High or moderate level of } \\
\text { social capital } \\
\text { - Low or very low level of } \\
\text { business sector R\&D ex- } \\
\text { penditure } \\
\text { - High or very high level of } \\
\text { governmental R\&D ex- } \\
\text { penditure } \\
\text { - High or very high level of } \\
\text { public sector R\&D person- } \\
\text { nel }\end{array}$ & $\begin{array}{l}\text { II- } \\
\text { imitative } \\
\text { regions }\end{array}$ & $\begin{array}{l}\text { - Low or very low level of human } \\
\text { capital } \\
\text { - Low or very low level of innova- } \\
\text { tion cooperation } \\
\text { - High or very high level of patent- } \\
\text { ing cooperation } \\
\text { - Low or very low rate of innovative } \\
\text { enterprises } \\
\text { - Low or moderate level of business } \\
\text { sector R\&D expenditure } \\
\text { - High or very high level of busi- } \\
\text { ness sector expenditure for the } \\
\text { acquisition of machinery, software } \\
\text { and equipment } \\
\text { - High or very high level of public } \\
\text { sector R\&D personnel }\end{array}$ \\
\hline $\begin{array}{l}\text { III - pri- } \\
\text { vate R\&D } \\
\text { based } \\
\text { regions }\end{array}$ & $\begin{array}{l}\text { - Low or very low level of } \\
\text { human capital } \\
\text { - High or very high level of } \\
\text { social capital } \\
\text { - High or very high level of } \\
\text { innovation cooperation } \\
\text { - High or very high rate of } \\
\text { innovation enterprises } \\
\text { - High or very high level of } \\
\text { business sector R\&D ex- } \\
\text { penditure } \\
\text { - Low or very low level of } \\
\text { business sector expenditure } \\
\text { for the acquisition of ma- } \\
\text { chinery, software and } \\
\text { equipment } \\
\text { - Low or very low level of } \\
\text { governmental R\&D ex- } \\
\text { penditure } \\
\text { - Very low level of public } \\
\text { sector R\&D personnel } \\
\end{array}$ & $\begin{array}{l}\text { IV - } \\
\text { diversi- } \\
\text { fied } \\
\text { innova- } \\
\text { tion } \\
\text { activity } \\
\text { regions }\end{array}$ & $\begin{array}{l}\text { - High or very high level of human } \\
\text { capital } \\
\text { - High or moderate level of social } \\
\text { capital } \\
\text { - High or very high level of patent- } \\
\text { ing cooperation } \\
\text { - High or moderate rate of innova- } \\
\text { tion enterprises } \\
\text { Very high, high or moderate level } \\
\text { of business sector R\&D expendi- } \\
\text { ture } \\
\text { - Low or moderate level of business } \\
\text { sector expenditure for the acquisi- } \\
\text { tion of machinery, software and } \\
\text { equipment } \\
\text { - High or moderate level of public } \\
\text { sector R\&D personnel } \\
\text { - Very high, high or moderate level } \\
\text { of patenting activity }\end{array}$ \\
\hline $\begin{array}{l}\text { V-un- } \\
\text { specific } \\
\text { group }\end{array}$ & \multicolumn{3}{|c|}{$\begin{array}{l}\text { Regions which are not characterised by any specific pattern in a given year. In the re- } \\
\text { maining years they are grouped within one of the four identified groups. }\end{array}$} \\
\hline
\end{tabular}

Source: Lubacha (2019: 234) 
Public R\&D based regions are mostly in Eastern Poland such as Podlaskie, Lubelskie and Świettokrzyskie; they are also part of a group of underdeveloped regions in Poland in terms of GDP (below $20 \%$ of the EU average in 2004, and below $30 \%$ in 2013). Diversified innovation activity regions - Małopolskie, Śląskie, Dolnośląskie, Pomorskie, and Mazowieckie - are regions with a high FDI share (from 5 [Małopolskie] to 19 [Mazowieckie] enterprises with foreign capital per 10,000 inhabitants in 2013) and a high level of new enterprise creation (almost $45 \%$ of all new enterprises created every year in Poland are established in those regions). Podkarpackie is an example of a private R\&D based region, and what is interesting is that data shows a low level of human capital, but a very high level of innovation cooperation. It can be assumed that capital and cooperation in the Podkarpackie region are high and they can support the innovation activity.

In the case of both models for innovation activity, the results of the Breusch-Pagan test ( $p>$ 0.05 ) do not allow the rejection of the hypothesis about a lack of individual effect. Likewise, the results of the Baltagi \& Li AR-RE test $(p>0.05)$ do not allow the rejection of the hypothesis about a lack of random effects. Therefore, the results of the OLS models can be interpreted as reliable (Table 4).

In the model for in-house R\&D activity $r d_{i t}$ ) ( innovation cooperation, public financing and the level of foreign capital in the region were found to be significant. Hypothesis 1 cannot be rejected because of the insignificance of variable $K 1$ for human capital. Hypotheses 2 and 4 can be confirmed, as the higher level of innovation cooperation and public financing were found to be positively related with the engagement of innovative enterprises in the in-house

R\&D. In the model for the acquisition of machinery and equipment ( ${ }^{m e_{i t}}$ ) $_{x}$ only innovation cooperation was found to be significant. Hypothesis 3 cannot be rejected because of the insignificance of the variable FCapital. Although, the level of foreign capital engagement in the region (enterprises with foreign capital) was found to be positively related to the in-house R\&D activity.

Table 4

Determinants of the two types of innovation activity

\begin{tabular}{|c|c|c|}
\hline Model & $r d_{i t}$ & $m e_{\text {it }}$ \\
\hline intercept & $2.9394(0.0000)^{* * *}$ & $4.3135(0.0000)^{* \star *}$ \\
\hline$K 1_{\text {it }}$ & $-0.0288(0.7383)$ & $-0.0322(0.4578)$ \\
\hline$C 1_{\text {it }}$ & $0.0721(0.0018)^{* *}$ & $0.0488(0.0007)^{\star \star \star}$ \\
\hline FCapital it $_{\text {it }}$ & $0.063(0.0388)$ * & $-0.0218(0.1663)$ \\
\hline PublicFin it & $0.1916(0.0001)^{* * *}$ & $-0.009(0.730)$ \\
\hline model's parameters & \multicolumn{2}{|c|}{ Balanced Panel: $n=16, T=5, N=80$} \\
\hline$R$-Squared & 0.26864 & 0.22799 \\
\hline Adj. R-Squared & 0.22963 & 0.18681 \\
\hline F-statistic & p-value: 0.0244 & p-value: 0.0362 \\
\hline
\end{tabular}

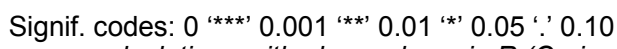

Source: own calculations with plm package in $R$ (Croissant and Millo 2008) 
For both types of innovation activity, the innovation cooperation was shown to be positively related. In the Polish regions, for the period 2004-2006, on average 56\% of innovative enterprises introduced an innovation developed by themselves, while in the years 2012-2014 it was $50 \%$. Nevertheless, an increase in the engagement of Polish enterprises in the development of innovation in cooperation is visible in the analysed period. In 2004-2006, only $7 \%$ (the average for the 16 NUTS-2 regions) of innovative enterprises introduced innovations developed in cooperation with Polish entities, and in the years $2012-2014$ it was $12 \%$. In the case of the introduction of innovations developed in an international cooperation, it was $2 \%$ in 2004-2006 and 4\% in 2012-2014, on average.

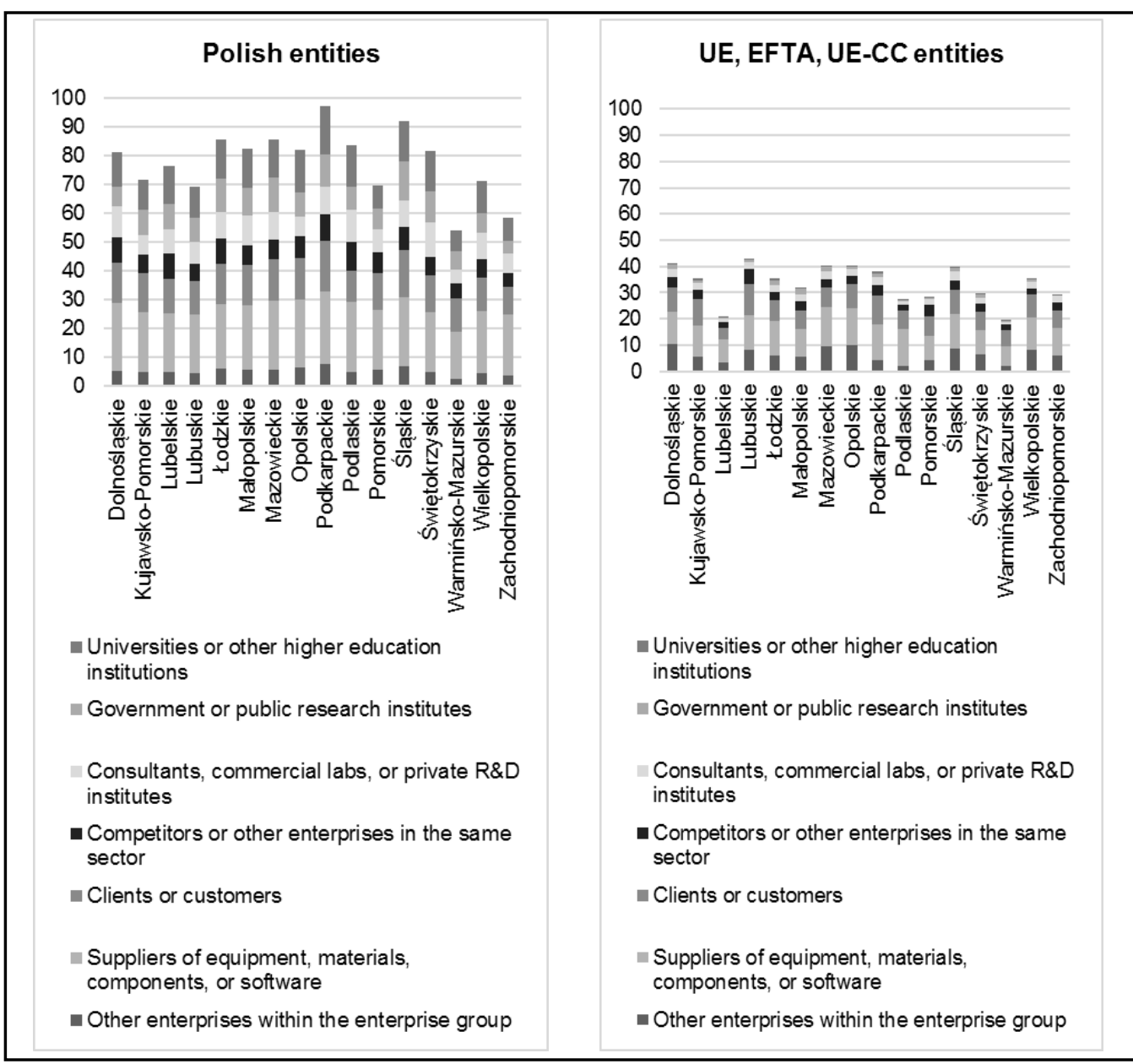

Fig. 2 - Breakdown of types of co-operators in innovation cooperation

with Polish and UE, EFTA, UE-CC entities (average for the years 2004-2014)

Notion: the CIS question about the type of cooperation is a multiple choice question, and the answers do not add up to $100 \%$

Source: own elaboration based on GUS (CIS) data. (Data from CIS were delivered by the Polish National Statistical Office (GUS) in the form of aggregated data at NUTS-2 level. The acquisition of data was financed by the National Science Centre, Poland, grant no. 2016/21/N/HS4/02098). 
Innovation cooperation can include various types of co-operators: other enterprises from the same group, suppliers, clients, competitors, but also private and public research units and higher education units. The main type of co-operators in the case of national cooperation are the suppliers $(16-25 \%)$, customers $(10-18 \%)$ and universities $(7-17 \%)$. Cooperation with international research units and universities is below $3 \%$. In the case of some regions, the more important partner in international rather than national cooperation are other enterprises within the enterprise group (Fig. 2).
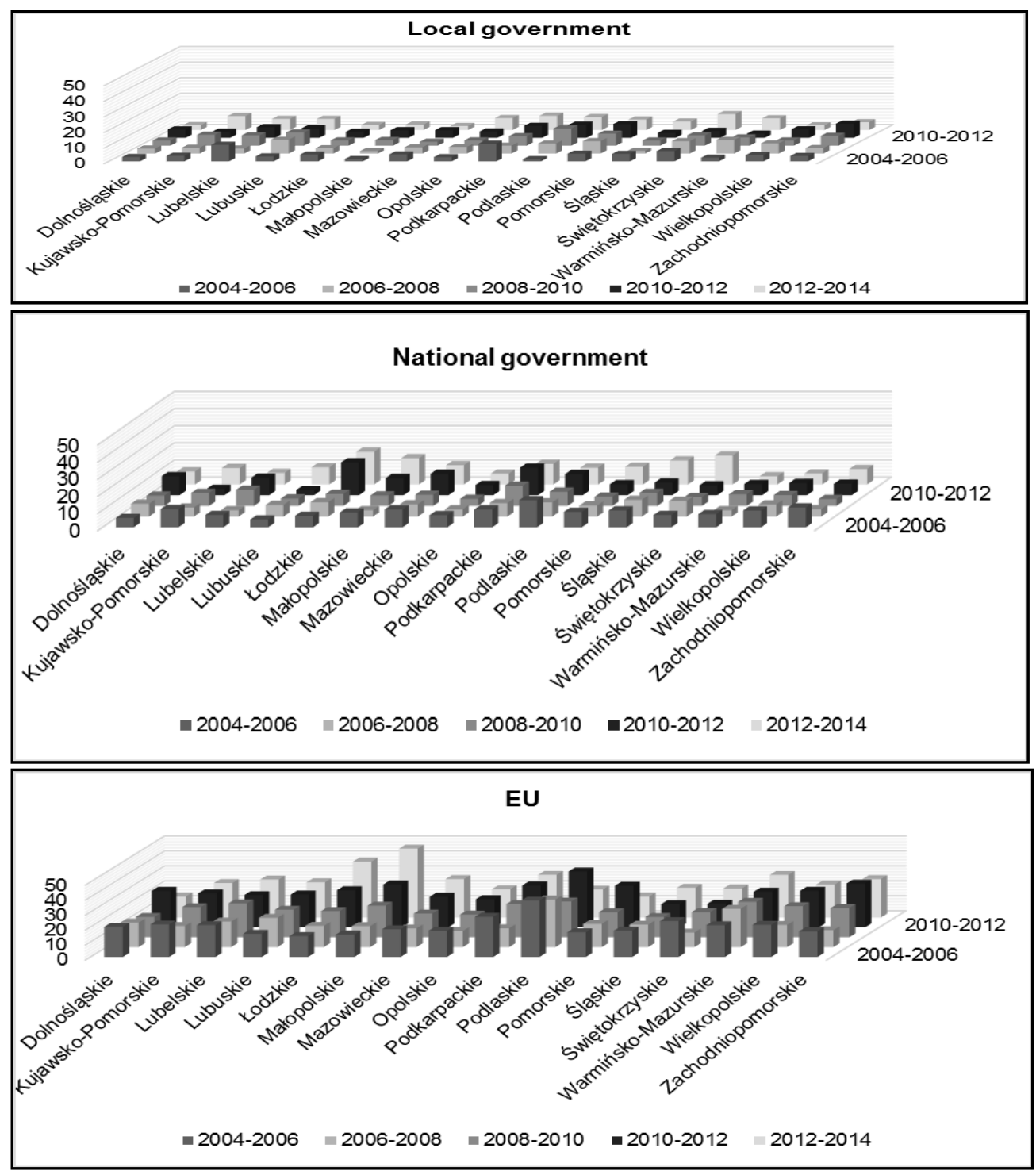

Fig. 3 - Percentage of innovative enterprises supported with external public funding (local, national, EU), in the years 2004-2014

Source: own elaboration based on GUS (CIS) data 
Public financial support is not limited to national government funding (the variable used in the model) but it includes regional governments' funding and EU funding. Regional and local governments supported, on average, from $3 \%$ to $8 \%$ of innovative enterprises in the years 2004-2014. National government supported from $5.5 \%$ to $12 \%$ on average. The highest level of financial support received by innovative enterprises in Polish regions was from $16 \%$ in the Świętokrzyskie region to $30 \%$ in Podlaskie, on average, for the years 2004-2014 (Fig. 3).

\section{Discussion}

Innovation cooperation was found to be significant and positively related with both types of innovation activity. This can be interpreted as confirmation of the high importance of cooperation and interaction among the various actors in the RIS concept (Cooke and Morgan 1998, Nauwelaers 2011, Tödtling and Trippl 2011). However, Broekel et al. (2015) warned that inter-regional and non-regional linkages should be balanced, and policy efforts should support both directions of cooperation. Moreover, Świadek et al. (2019) found an interesting relation between the level of technology and the innovation cooperation in the Polish industry. Low technology industries were less involved in innovation cooperation than high-tech ones. Although, low-tech companies cooperate more with suppliers, and high-tech ones more with competitors. Fritsch (2003) discussed that the tendency to cooperate is more a firm-level phenomenon and companies which start any type of cooperation tend to cooperate more with various types of actors. Nevertheless, lammarino et al. (2012) find out that vertical cooperation (eg. with suppliers, research units, clients) is more significant for increasing the innovativeness of the firms in contrast to horizontal cooperation (eg. with consultant or competitors)

As it was expected, public financial support was also found to be positively related with the inhouse R\&D activity. However, data shows that EU funding is the predominant form of public financial support. Lewandowska et al. (2019) reported that Polish enterprises were very active in utilising EU funds and other EU economic policy instruments, but there are not so many Polish national government financial instruments available. Although, as Mazzucato and Semieniuk (2017) stressed out, there is a need for "mission-oriented policies", and the development of public financing instruments as part of innovation systems. Public funding is also seen as an instrument complementing private efforts (Spielkamp and Rammer 2009, Kijek et al. 2016) and an important factor reducing the exit from the market by innovative firms (Ebersberger 2011). However, there is evidence (Novosák et al. 2017) that public support, especially Structural Funds, are more effective in already developed regions.

Interestingly, the level of foreign capital engagement in the region (enterprises with foreign capital) was found to be positively related with the in-house R\&D activity, which is contradicted with research at the national level, where Polish enterprises are seen more as buyers of already developed technology (Grodzicki and Geodecki 2016, Grodzicki 2018). On the other hand, the positive effect of foreign capital on the in-house R\&D activity is in line with Fu's (2008) suggestions that FDI can support both types of innovation activity. It can be assumed that enterprises in the Polish regions are able to use foreign investments as a way to support their own R\&D activities. Surprisingly, human capital was found to be insignificant in the model for in-house R\&D activity, although this can be due to the indicators used. Human capital can be captured by various indicators ( $\%$ of population with higher education, $\%$ of graduates in specific fields of studies, \% of population taking part in life-long-learning), and, in the present research, the indicator most related to the R\&D activity was chosen.

\section{Conclusions}

In the research, the regional factors of two types of innovation activity - in-house R\&D and the acquisition of machinery and software - were analysed. Special attention was paid to the role of cooperation in RISs and innovation activity. Based on econometric models, it was confirmed 
that innovation cooperation, public financial support and the level of foreign capital involvement in the region are positively related with in-house R\&D activity. However, in 2012-2014, only $12 \%$ of innovative enterprises developed innovations in cooperation with national partners, and $2 \%$ with international partners. Innovative companies in Polish regions cooperate mostly with national and international suppliers, and with Polish research institutes and universities. Likewise, customers and clients are important partners for innovation cooperation. National financial support was found to be positively related with in-house R\&D activity, nevertheless, national public funding was received by up to $19 \%$ of innovative enterprises in the years 20122014, while EU funds supported up to $46 \%$ in the same period. It can be assumed that the EU offers funding which is more adjusted to the needs of innovative enterprises.

The following policy implications can be drawn based on the obtained results. As innovation cooperation was found to be positively related with both types of innovation activity, it can be seen as important factor of introducing innovations, no matter if an innovation is developed based on the in-house R\&D activity or based on the acquisition of already existing technology. Therefore, any public incentives for cooperation can play a supportive role for innovative firms to introduce innovations. What can be more relevant is the significance of public financial support, which was found positively related to the in-house R\&D activity. Based on the findings from growth literature, signalled in the introduction, it can be suggested that by supporting the $R \& D$ activity of companies we indirectly support the economic growth in the region. Therefore, public financial instruments for innovative companies should be mainly aimed at supporting the R\&D activity, instead of the acquisition of machinery and software (which is more often observed in the Polish regions).

\section{Acknowledgements}

The present research is a part of the project "Socio-economic environment in a region and types of innovation activity of enterprises", which is financed by the National Science Centre, Poland, grant no. 2016/21/N/HS4/02098.

\section{References}

ABRAMOVITZ M. (1956), Resource and Output Trends in the United States since 1870, National Bureau of Economic Research, New York.

ACS Z. J., FITZROY F. R., SMITH I. (1998), Contrasting U.S. Metropolitan Systems of Innovation, in: de la Mothe J., Paquet G. (eds.), Local and Regional Systems of Innovation, Springer, New York, pp. 111-124.

ASHEIM B. T., ISAKSEN A. (1997), Location, agglomeration and innovation: Towards regional innovation systems in Norway?, European Planning Studies 5 (3), 299-330.

ASHEIM B. T., ISAKSEN A. (2002), Regional Innovation Systems: The Integration of Local 'Sticky' and Global 'Ubiquitous' Knowledge, The Journal of Technology Transfer 27, 7786.

AUTIO E. (1998), Evaluation of RTD in regional systems of innovation, European Planning Studies 6 (2), 131-140. Chichester

BALTAGI B. H. (2005), Econometric Analysis of Panel Data, John Wiley \& Sons Ltd,

BALTAGI B. H., LI Q. (1991), A joint test for serial correlation and random individual effects, Statistics \& Probability Letters 11 (3), 277-280.

BALTAGI B. H., LI Q. (1995), Testing AR(1) against MA(1) disturbances in an error component model, Journal of Econometrics 68 (1), 133-151.

BECKER G. S., MURPHY K. M., TAMURA R. (1990), Human Capital, Fertility, and Economic Growth, Journal of Political Economy 98 (5), 12-37.

BELLMAN L., CRIMMANN A., EVERS K., HUJER R. (2013), Regional Determinants of 
Establishments' Innovation Activities: A Multi-Level Approach, IZA Discussion Paper 7572, 130.

BRACZYK H.-J., COOKE P., HEIDENREICH M. (eds.) (1998), Regional innovation systems: the role of governances in a globalized world, Routledge, London.

BREUSCH T. S., PAGAN A. R. (1980), The Lagrange Multiplier Test and its Applications to Model Specification in Econometrics, The Review of Economic Studies 47 (1), 239-253.

BROEKEL T., BRENNER T. (2011), Regional factors and innovativeness: an empirical analysis of four German industries, The Annals of Regional Science 47, 169-194.

BROEKEL T., BRENNER T., BUERGER M. (2015), An Investigation of the Relation between Cooperation Intensity and the Innovative Success of German Regions, Spatial Economic Analysis 10 (1), 52-78.

BUESA M., MARTÍNEZ PELLITERO M., BAUMART T., HEIJS J. (2007), Novel applications of existing econometric instruments to analyse regional innovation systems: the Spanish case, in: Suriñach J., Moreno R., Vayá E. (eds.), Knowledge Externalities, Innovation Clusters and Regional Development, Edward Elgar, Cheltenham, pp. 155-174.

CAMAGNI R., CAPELLO R. (2013), Regional Innovation Patterns and the EU Regional Policy Reform: Toward Smart Innovation Policies, Growth and Change 44 (2), 355-389.

COOKE P., ASHEIM B., BOSCHMA R., MARTIN R., SCHWARTZ D., TÖDTLING F. (eds.) (2011), Handbook of regional innovation and growth, Edward Elgar, Cheltenham. COOKE P., MORGAN K. (1998), The associational economy: Firms, regions, and innovation, Oxford University Press, Oxford.

COOKE P., GOMEZ URANGA M., ETXEBARRIA G. (1997), Regional innovation systems: Institutional and organisational dimensions, Research Policy 26 (4-5), 475-491.

COUNCIL ON COMPETITIVENESS (2005), Measuring regional innovation: a guidebook for conducting regional innovation assessments, Council on Competitiveness, Retrieved from: www.compete.org.

CRESCENZI R. (2005), Innovation and regional growth in the enlarged Europe: the role of local innovative capabilities, peripherality, and education, Growth and Change 36 (4), 471 507.

CRESCENZI R., RODRÍGUEZ-POSE A. (2011), Innovation and Regional Growth in the European Union, Springer, Berlin. CRESCENZI R., RODRÍGUEZ-POSE A. (2013), R\&D, Socio-Economic Conditions, and Regional Innovation in the U.S., Growth and Change 44 (2), 287-320.

CROISSANT Y., MILLO G. (2008), Panel Data Econometrics in R: The plm Package, Journal of Statistical Software 27 (2), 1-43.

CZUPICH M. (2012), Uwarunkowania wzrostu innowacyjności w wybranych krajach

Europy Środkowo-Wschodniej [Factors of innovation growth in selected Central and Eastern European Countries], Zeszyty Naukowe Uniwersytetu Szczecińskiego nr. 725, Ekonomiczne Problemy Usług nr. 98, 205-219.

DAVIDSON C., SEGERSTROM P. (1998), R\&D Subsidies and Economic Growth, The RAND Journal of Economics 29 (3), 548-577.

DOLOREUX D. (2002), What we should know about regional systems of innovation Technology in Society 24 (3), 243-263.

DOLOREUX D., GOMEZ I. P. (2017), A review of (almost) 20 years of regional innovation systems research, European Planning Studies 25 (3), 371-387.

DOLOREUX D., PARTO S. (2004), Regional innovation systems: a critical synthesis, UNU-INTECH Discussion Papers, 1-38.

DOLOREUX D., PARTO S. (2005), Regional innovation systems: Current discourse and unresolved issues, Technology in Society 27 (2), 133-153.

DZEMYDAITĖ G., DZEMYDA I., GALINIENE B. (2016), The Efficiency of Regional Innovation Systems in New Member States of the European Union: A Nonparametric DEA Approach, Economics and Business 28 (1), 83-89. 
DZIALLAS M., BLIND K. (2019), Innovation indicators throughout the innovation process: An extensive literature analysis, Technovation 80-81, 3-29.

EBERSBERGER B. (2011), Public funding for innovation and the exit of firms, Journal of Evolutionary Economics 21, 519-543.

EUROPEAN COMMISSION (2010a), Communication from the Commission: Europe 2020. A strategy for smart, sustainable and inclusive growth, European Commission, Retrieved from: www.eur-lex.europa.eu.

EUROPEAN COMMISSION (2010b), Communication from the Commission to the European Parliament, the Council, the European Economic and Social Committee and the Committee of the Regions: Regional Policy contributing to smart growth in Europe 2020, European Commission, Retrieved from: www.eur-lex.europa.eu.

EVANGELISTA R., IAMMARINO S., MASTROSTEFANO V., SILVANI A. (2002), Looking for regional systems of innovation: evidence from the Italian innovation survey, Regional Studies 36 (2), 173-186.

FAGERBERG J., GODINHO M. M. (2005), Innovation and catching-up, in: Fagerberg J., Mowery D. C., Nelson R. R. (eds.), The Oxford Handbook of Innovation, Oxford University Press, Oxford, pp. 514-542.

FLORIO M., PELLEGRIN J., SIRTORI E. (2014), Research Intensive Clusters and Regional Innovation Systems: A Case Study of Mechatronics in Apulia, Centre for Industrial Studies: Working Paper Series, 3, 1-35.

FRITSCH M. (2003), Does R\&D-Cooperation Behavior Differ between Regions?, Industry and Innovation 10 (1), 25-39.

FU X. (2008), Foreign Direct Investment, Absorptive Capacity and Regional Innovation Capabilities: Evidence from China, Oxford Development Studies 36 (1), 89-110.

GEODECKI T. (2014), Leading Factors for Catching-Up by Developing Economies: Conclusions from the crisis, in: Mamica Ł., Tridico P. (eds.), Economic Policy and the Financial Crisis, Routledge, London, New York, pp. 181-203.

GERSTLBERGER W. (2004), Regional innovation systems and sustainability-selected examples of international discussion, Technovation 24 (9), 749-758.

GRIFFITH R., REDDING S., VAN REENEN J. (2004), Mapping the Two Faces of R\&D: Productivity Growth in a Panel of OECD Industries, Review of Economics and Statistics 86 (4), 883-895.

GRODZICKI M. J. (2018), Konwergencja w warunkach integracji gospodarczej. Grupa Wyszehradzka w globalnych łańcuchach wartości [Convergence in the conditions of economic integration. The Visegrad Group in global value chains], Wydawnictwo Uniwersytetu Jagiellońskiego, Kraków.

GRODZICKI M. J., GEODECKI T. (2016), New Dimensions of Core-Periphery Relations in an Economically Integrated Europe: The Role of Global Value Chains, Eastern European Economics 54 (5), 377-404.

HÁJKOVÁ V., HÁJEK P. (2010), Analysis of regional innovation systems by neural networks and cluster analysis, COMATIA'10: Proceedings of the 2010 international conference on Communication and management in technological innovation and academic globalization, 46-51.

HOWELLS J. (1999), Regional systems of innovation?, in: Archibugi D., Howells J., Michie J. (eds.), Innovation Policy in a Global Economy, Cambridge University Press, Cambridge, pp. 67-93.

IAMMARINO S. (2005), An evolutionary integrated view of regional systems of innovation: Concepts, measures and historical perspectives, European Planning Studies 13 (4), 497-519.

IAMMARINO S., PIVA M., VIVARELLI M., VON TUNZELMANN N. (2012), Technological Capabilities and Patterns of Innovative Cooperation of Firms in the UK Regions, Regional Studies 46 (10), 1283-1301.

INNOVATING REGIONS IN EUROPE (2008), Innovating Regions in Europe, ERIS WG 
Final Report, Retrieved from: www.wbc-rti.info.

KIJEK T., MATRAS-BOLIBOK A., RYCAJ E. (2016), Do Public R\&D Expenditures Foster Business R\&D Investments?, International Journal of Synergy and Research 5, 147154.

KOSAŁA M., WACH K. (2011), Regionalne determinanty rozwoju innowacyjności przedsiębiorstw [Regional determinants of innovation development], Zeszyty Naukowe Uniwersytetu Ekonomicznego w Krakowie 866, 19-36.

KRAKOWIAK-BAL A., ZIEMIAŃCZYK U. (2017), Factors Influencing the Level of Regional Innovation - Qualitative Comparative Analysis, Barometr Regionalny 15 (4), 7-14.

LEWANDOWSKA A., PATER R., CYWIŃSKI Ł. (2019), Determinants of business innovation in the Regional Innovation System context. Policy implications for a less developed region, Studia Regionalne i Lokalne 1 (75), 5-27.

LIGENZOWSKA J. (2016), Regional Innovation Systems in Sweden, Ekonomia Międzynarodowa 16, 388-405.

LOPEZ-RODRIGUEZ J., MARTINEZ-LOPEZ D. (2017), Beyond the R\&D effects on innovation: The contribution of non-R\&D activities to total factor productivity growth in the EU, Structural Change and Economic Dynamics 40, 37-45.

LUBACHA J. (2019), Regional innovation systems of Polish regions, in: Balcerzak A. P., Pietryka I. (eds.), Proceedings of the 10th International Conference on Applied Economics Contemporary Issues in Economy: Economics, pp. 226-235.

MARKOWSKA M. (2012), Dynamiczna taksonomia innowacyjności regionów [Dynamic taxonomy of regional innovativeness], Wydawnictwo Uniwersytetu Ekonomicznego we Wrocławiu, Wrocław.

MARTIN B. R. (2013), Innovation Studies: An Emerging Agenda, in: Fagerberg J., Martin B. R., Andersen E. S. (eds.), Innovation Studies: Evolution \& Future Challenges, Oxford University Press, Oxford, pp. 168-186.

MAZZUCATO M. (2013), The Entrepreneurial State: debunking public vs. private sector myths, Anthem Press, London.

MAZZUCATO M., SEMIENIUK G. (2017), Public financing of innovation: new questions, Oxford Review of Economic Policy 33 (1), 24-48.

MILLO G. (2017), Robust Standard Error Estimators for Panel Models: A Unifying Approach, Journal of Statistical Software 82 (3), 1-27.

NAUWELAERS C. (2011), Intermediaries in regional innovation systems: role and challenges for policy, in: Cooke P., Asheim B., Boschma R., Martin R., Schwartz D., Tödtling F. (eds.), Handbook of regional innovation and growth, Edward Elgar, Cheltenham, pp. 467-481.

NAZ A., NIEBUHR A., PETERS J. C. (2015), What's behind the disparities in firm innovation rates across regions? Evidence on composition and context effects, The Annals of Regional Science 55, 131-156.

NIEDZIELSKI P., JAŹWIŃSKI I. (2002), Absorpcja i dyfuzja innowacji jako czynnik intensyfikujący rozwój regionalny [Absorption and diffusion of innovation as a factor of regional development], Zeszyty Naukowe WSZ „Oeconomicus” PTE w Szczecinie „Gospodarka-Rozwój i Zmiany" 2.

NÖLKE A., VLIEGENTHART A. (2009), Enlarging the Varieties of Capitalism: The Emergence of Dependent Market Economies in East Central Europe, World Politics 61 (4), 670 $-702$.

NOVOSÁK J., HÁJEK O., NOVOSÁKOVÁ J., LINDNER M. (2017), Enterprise Support Policy and Territorial Cohesion: The Czech Republic (2007-2013), Journal of Urban and Regional Analysis 9 (2), $141-157$.

NOWAKOWSKA A. (2011), Regionalny wymiar procesów innowacji [The regional dimension of innovation processes], Wydawnictwo Uniwersytetu Łódzkiego, Łódź.

OECD, EUROSTAT (2018), Oslo Manual 2018: Guidelines for Collecting, Reporting and Using Data on Innovation, 4th Edition, The Measurement of Scientific, Technological and Innovation Activities, OECD Publishing, Paris/Eurostat, Luxembourg. 
PAAS T., TRIIN V. (2012), Regional Disparities and Innovations in Europe, 52nd Congress of the European Regional Science Association: "Regions in Motion - Breaking the Path", 21-25 August 2012, Bratislava, Slovakia, 1-16.

PANGSY-KANIA S. (ed.) (2007), Wiedza i innowacje w rozwoju polskich regionów: siły motoryczne i bariery [Knowledge and innovations in the development of Polish regions: motor forces and barriers], Fundacja Rozwoju Uniwersytetu Grańskiego, Sopot.

PARK S. O. (2015), Dynamics of economic spaces in the global knowledge-based economy: Theory and East Asian cases, Routledge, London, New York.

PINO R. M., ORTEGA A. M. (2018), Regional innovation systems: Systematic literature review and recommendations for future research, Cogent Business \& Management 5 (1), 1463606.

PUTNAM R. D., LEONARDI R., NONETTI R. Y. (1993), Making Democracy Work: Civic Traditions in Modern Italy, Princeton University Press, Princeton.

RADOSEVIC S., KADERABKOVA A. (eds.) (2011), Challenges for European Innovation Policy: Cohesion and Excellence from a Schumpeterian Perspective, Edward Elgar, Cheltenham.

R CORE TEAM (2018), R: A language and environment for statistical computing, $\mathrm{R}$ Foundation for Statistical Computing, Retrieved from: www.R-project.org.

ROMER P. M. (1990), Endogenous Technological Change, Journal of Political Economy 98 (5), S71-S102.

SEGERSTROM P. S. (1991), Innovation, Imitation, and Economic Growth, Journal of Political Economy 99 (4), 807-827.

SMITH H. L., KEEBLE D., LAWSON C., MOORE B., WILKINSON F. (1998),

Contrasting Regional Innovation Systems in Oxford and Cambridge, in: de la Mothe J., Paquet G. (eds.), Local and Regional Systems of Innovation, Springer, New York, pp. 125-148. SOLOW R. M. (1956), A Contribution to the Theory of Economic Growth, The Quarterly Journal of Economics 70 (1), 65-94. SOLOW R. M. (1957), Technical Change and the Aggregate Production Function, The

Review of Economics and Statistics 39 (3), 312-320. SPIELKAMP A., RAMMER C. (2009), Financing of Innovation - Thresholds and Options, Management \& Marketing 4 (2), 3-18. ŚWIADEK A. (2011), Regionalne systemy innowacji w Polsce [Regional innovation systems in Poland], Difin, Warszawa.

ŚWIADEK A., DZIKOWSKI P., TOMASZEWSKI M., GORĄCZKOWSKA J. (2019), Sectoral patterns of innovation cooperation in Polish industry, Equilibrium. Quarterly Journal of Economics and Economic Policy 14 (1), 183-200.

TÖDTLING F., TRIPPL M. (2011), Regional innovation systems, in: Cooke P., Asheim

B., Boschma R., Martin R., Schwartz D., Tödtling F. (eds.), Handbook of regional innovation and growth, Edward Elgar, Cheltenham, pp. 455-466.

TURA T., HARMAAKORPI V. (2010), Social capital in building regional innovative capability, Regional Studies 39 (8), 1111-1125.

VEUGELERS R., MRAK M. (2009), The Knowledge Economy and Catching-up Member States of the European Union, Report prepared for Commissioner's Potocnik's Expert Group "Knowledge for Growth", Retrieved from: www.ec.europa.eu.

WERESA M. A. (2012), Systemy innowacyjne we współczesnej gospodarce światowej [Innovative systems in the contemporary global Economy], Wydawnictwo Naukowe PWN, Warszawa.

WERESA M. A. (2013), Regional Innovation Systems and Innovation Policy: Polish Regions Compared with Other Regions in the EU, in: Weresa M. A. (ed.), Poland Competitiveness Report 2013: National and Regional Dimensions, Warsaw School of Economics Press, Warsaw, pp. 278-298.

WIIG H., WOOD M. (1995), What Comprises a Regional Innovation System? An Empirical Study, STEP, Oslo.

YUAN C., GUO B., LIU H. (2013), Assessment and classification of China's provincial 
Judyta LUBACHA

regional innovation system based on grey fixed weight clustering, Grey Systems: Theory and Application 3 (3), 316-337.

Initial submission: 22.02.2020

Revised submission: 27.07.2020

Final acceptance: 01.10 .2020

Correspondence: Institute of Economics, Finance, and Management, Faculty of Management and Social Communication, Jagiellonian University, prof. S. Łojasiewicza Str. 4, 30-348 Cracow, Poland; Faculty of Economics and International Relations, Cracow University of Economics, ul. Rakowicka 27, 31-510 Cracow, Poland.

Email: judyta.lubacha@uj.edu.pl 